\title{
風洞水槽におけるコンテナ模型の流動に与える 風と流れの効果に関する実験 EXPERIMENTS OF EFFECTS OF WIND AND WIND-DRIVEN CURRENT ON CONTAINER MODEL DRIFT IN WIND-WAVE CHANNEL
}

\author{
熊谷兼太郎1・根木貴史2 \\ Kentaro KUMAGAI and Takashi NEGI \\ 1正会員 博(工) 国土交通省国土技術政策総合研究所 沿岸海洋研究部 \\ （２39-0826 神奈川県横須賀市長瀬3 1- 1) \\ 2正会員 工修 国土交通省国土技術政策総合研究所 沿岸海洋研究部沿岸防災研究室
}

\begin{abstract}
In this study, experiments were conducted on the effects of a container drifted by wind, wind-driven current and wave of a wind-wave channel. The channel is $28.5 \mathrm{~m}$ in length, $1.3 \mathrm{~m}$ in height and $1.5 \mathrm{~m}$ in width. The wind blown into the channel drives the wind-driven current and wave. In the case that the blower operated at $300 \mathrm{rpm}$, the kinematic eddy viscosity $\mathrm{K}_{\mathrm{Z}}$ was measured as $3.46 \mathrm{~cm}^{2} / \mathrm{s}$ at the fetch $x=18 \mathrm{~m}$ and $0.475 \mathrm{~m}$ above the water surface.

The container model is $1 / 20$ scale of 40 feet container. At the middle of the channel, the container model is floated on the surface of the water and is stilled at its initial position by a rigid steel base. The container model is forced by wind-drag, wind-wave and drag of the wind-driven current. The drag force and force of wind driven current acted on the container model were estimated by calculation in balance of the forces. The result is compared to the drag force coefficient and coefficient of force of wind driven current proposed by the previous researches.
\end{abstract}

Key Words : Container model, drag force, wind-driven current, wind-wave channel

\section{1. 研究の背景と目的}

2004年，水島港で台風第16号に伴う高潮によりコ ンテナがふ頭から流出する被害が発生した。流出し たのは15個の空コンテナで，いずれも港湾内を漂流 して約300 m離れた場所に到達した。その場所に あった防波堤の一部は損傷しており，損傷の原因の 一つとしてコンテナ衝突の可能性があると考えられ ている。このような，港湾に蔵置された貨物が流出 し海上を漂流する挙動について，被害を予測し対策 を検討する必要がある。

検討対象として，海上貨物輸送に汎用的に用いら れ，港湾に多数が蔵置されている国際貨物コンテナ

（以下，「コンテナ」という。）を考える.

コンテナの漂流については，仏ブルターニュ地方 の西部海域で実物コンテナを数時間漂流させる実験 が行われている1).また, Dani el et al. ${ }^{2)}$ は海上 に浮遊するコンテナに作用する風及び流れによる力 の定式化を行うとともに，1993年に発生した海難事 故でコンテナが数日間漂流した事例と比較すること により適用性の検討を行っている。これらのコンテ ナの漂流に関する実験または事例には, 複雑に変化 する気象や海流の及ぼす影響が含まれている。それ に対して，実験室で環境を制御した実験を行い，風，
流れ及び波がコンテナの漂流に及ぼす影響について 検討を行うことは有用と考えられる。

そこで本研究では，風の吹く海域を模擬した風洞 水槽で水面上に浮遊するコンテナ模型の流動に与え る風と流れの効果に関する実験を行い, 海域に流出 したコンテナの流動の特性を把握することとした.

\section{2. 実験の条件と方法}

\section{(1) 実験水路}

実験は，2010年11月〜翌2月に国土技術政策総合 研究所の風洞水槽で行った。この風洞水槽は, 既往 の報告3で用いたものと同じ水槽である。図-1は, 水槽の見取図で, 測定部は長さ28.5 m 高さ1.3 m 幅1. $5 \mathrm{~m}$ 万一様断面で, 本研究では水深 $h_{0}=0.4 \mathrm{~m}$ で湛水した。すなわち, 静水面上の空気部分の高さ は0.9 mだある。測定部の上流側には送風機が接続 されており，送風機によって起こされた風は整流板， 金網等により大きな乱れや不均一が生じないように したうえで，吹出口より測定部に送り込まれる。送 風量は送風機の回転数を制御し調整する。本研究で は回転数を200 r pm $300 \mathrm{rpm}$ 2段階で変化させた。 実験は主として断面C〜Dの間で行った. 


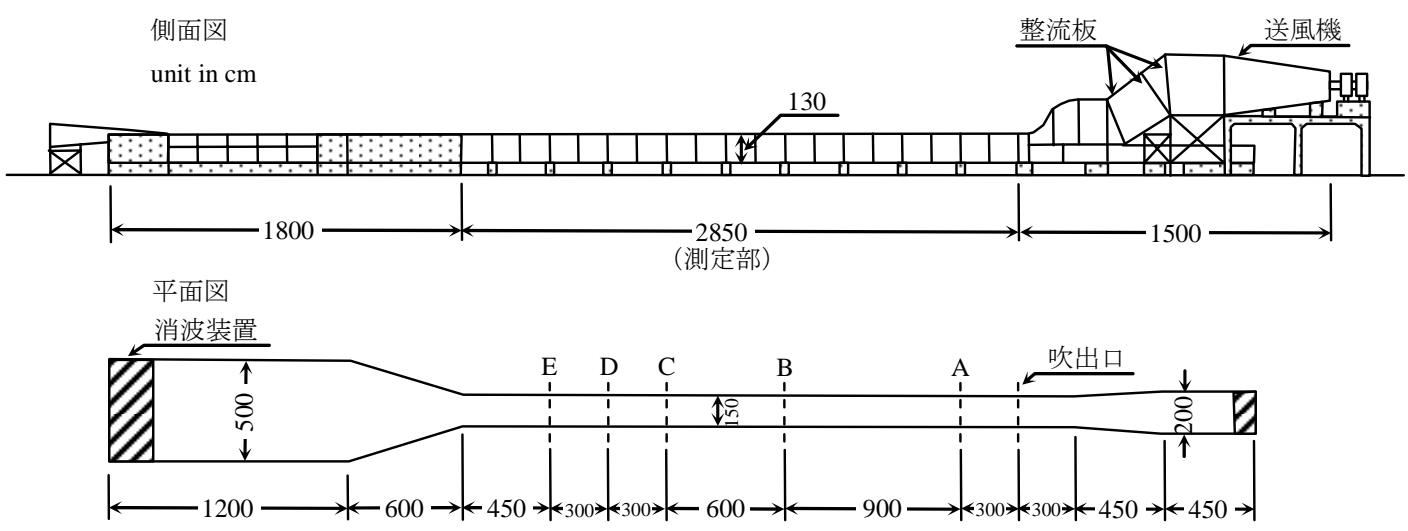

図-1 風洞水槽の見取図

\section{（2）風速の測定}

風速の測定は, 熱線流速計（日本カノマックス株 式会社製CTAユニットMODEL1011，X字型プローブ O249R- T5, 温度補償・リニアライザー機能付き) を 用いた。熱線流速計の測定值の検定はピトー管（株 式会社岡野製作所製LK 1S）及び微差圧計（株式会 社山本電機製作所製W081）による測定值と比較する ことにより行った.

風速の測定時間間隔は0.01 s とし，一定時間（60 s）の測定值を平均することにより平均風速 $u_{a}$ を求 めた. 測定位置は図-1の断面Cの横断方向中央位置 で，鉛直方向に高さを変えて測定した，なお，実験 期間中の環境は気温 $7 \sim 20^{\circ} \mathrm{C}$, 水温 $8 \sim 15^{\circ} \mathrm{C}$, 気圧 999〜1039 hPa，湿度34〜 81\% という範囲であった。

図-2は，断面Cの主流方向の風速 $u_{a}$ の分布である。 $z$ は静水位 $h_{0}$ からの高さである. $z$ が大きくなるに従 い，風速が大きくなっている．図中の実線と破線は， 以下のように求めて書き加えたものである。すなわ ち, 水がない固定壁面の場合と同様に, 波立った水 面上の境界層の内部領域には壁面からの距離に関し て風速が対数的に変化する対数分布則が適用できる と仮定する。 また, fully roughな状態にあると仮 定して, $u_{a}$ に以下の対数分布則を適用する：

$$
\frac{u_{a}}{u_{*}}=\frac{1}{\kappa} \ln \frac{z}{z_{0}}
$$

ここで，u*は摩擦速度， $\mathrm{K}$ は Karman 定数で 0.4 とする． $z_{0}$ は壁面粗度を表すパラメータである。な お，上の仮定については議論が必要であるが，ここ では加藤ら 4) と同様に式(1) が成立するものとして 考える. 図- 2 の測定点のうち，200r pm の場合は水 面に近い 7 点 $(z=0.040 \sim 0.170 \mathrm{~m})$ について, 分 布形状から判断して内部領域にあって式(1) が成立 すると考え，近似すると， $u_{*}=0.181 \mathrm{~m} / \mathrm{s}$ となった． さらに， $z_{0}$ を求め書き加えたものが図中の実線であ る.ただし，このときの $z_{0}$ は $5.73 \times 10^{6} \mathrm{~m}$ と非常 に小さくなったので, 水面近傍 $(z=0.040 \mathrm{~m}$ より も水面に近い位置）での測定をより詳細に行う等の 精度向上が今後必要であると考えられる．300r pm
の場合も同様に水面に近い 4 点 $(z=0.065 \sim 0.125$ m) について近似して, $u_{*}=0.262 \mathrm{~m} / \mathrm{s}, z_{0}=$ 7. $58 \times 10^{6} \mathrm{~m}$ 求めた。 それを書き加えたものが図 中の破線である.

図-3は， $u_{a}$ をu*で，また， $z$ を(3)の波高の測定結 果より求めた断面C位置の有義波高 $h_{1 / 3}$ で無次元化し た風速分布を示す. なお， (1) 式から求めた $z_{0}$ は非 常に小さかったことを考慮して，ここではzの無次

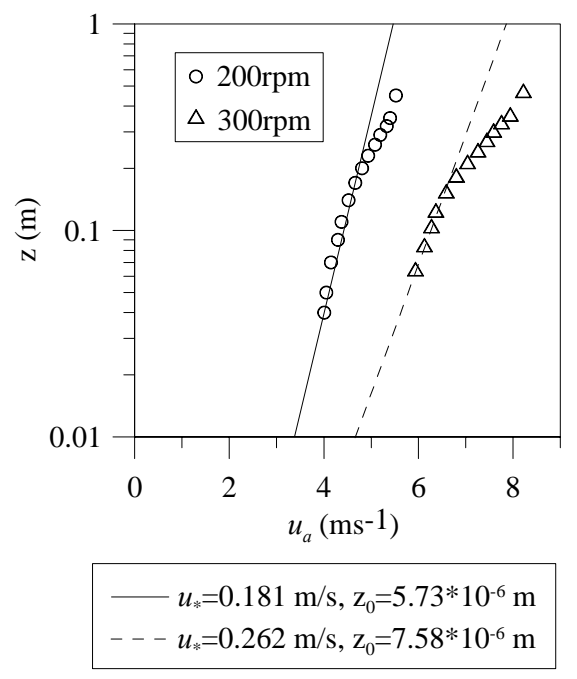

図-2 風速分布 (断面C)

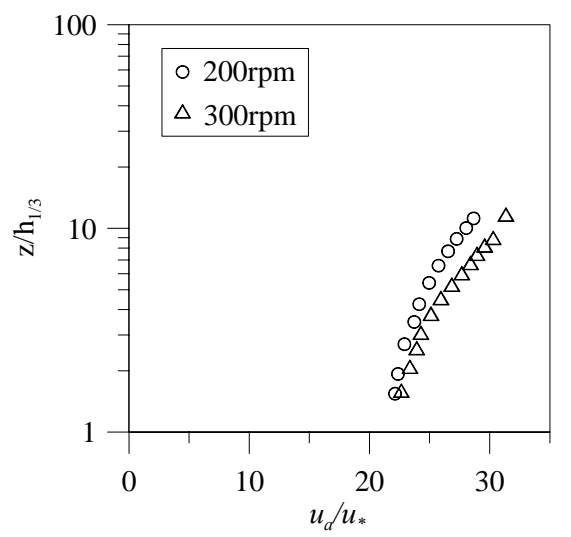

図-3 無次元化した風速分布 
元化のために水面の状態を代表する指標の一つと考 えられる $h_{1 / 3}$ を用いた． $h_{1 / 3}$ は200r pmoとき0.0259 m 300r pm) とき0.0406 mである.

図一4は, $z$ を後述するコンテナ模型の高さ $H$ $(0.130 \mathrm{~m})$ で無次元化した風速分布を示す. 図- 3 と比較すると, $200 \mathrm{r}$ pm 場合と300r pmm場合の分布 のずれが小さくなってほぼ重なっている.

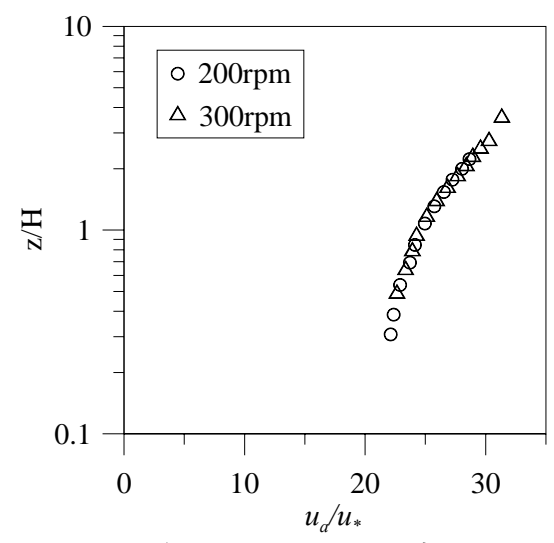

図-4 無次元化した風速分布

図-5は，風速の測定結果の例を示す。ここでは， 測定間隔を $100 \mathrm{H}_{2}$ で測定した流速を, 断面Cの 200r pm ときの測定開始〜1 sの間を例として主流 方向及び鉛直方向についてそれぞれ示した。いずれ も波形の峯と谷が明確に測定できていることから， 風速の乱れの各成分 $u^{\prime} 及 ひ ゙ w^{\prime}$ を測定するための測定 間隔は100 Hで十分であると判断した.

図-6は，断面Cの乱礼成分平均值 $\overline{u^{\prime} w^{\prime}}$ の鉛直分布, 渦動粘性係数（式(2)）の鉛直分布をそれぞれ示す.

$$
K_{z}=\frac{-\overline{u^{\prime} w^{\prime}}}{\frac{\partial \overline{u_{a}}}{\partial z}}
$$

$\overline{u^{\prime} w^{\prime}}$ は， $z=0.2$ 付近まではばらつきが大きいが，そ れより $z$ が大きくなると概ね小さくなっている。ま た， $K_{\mathrm{z}}$ は，300r pm门ときに $z=0.475 \mathrm{~m}$ 位置で $K_{\mathrm{z}}=$

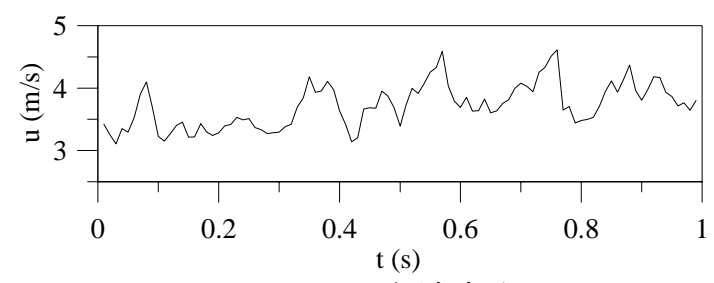

(1) 主流方向



(2) 鉛直方向

図-5 風速の測定結果の例（200r pm)

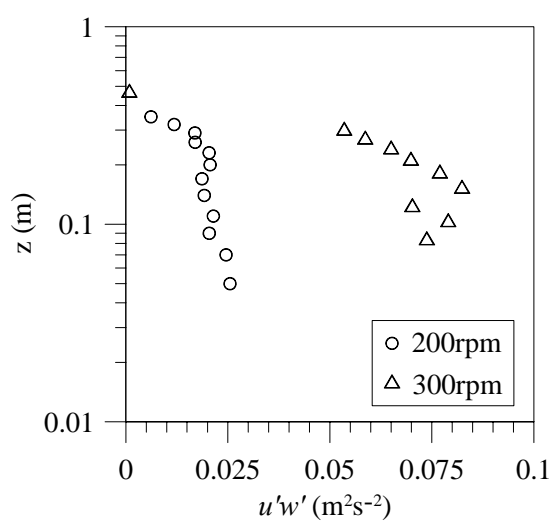

（1）乱れ成分平均值の鉛直分布

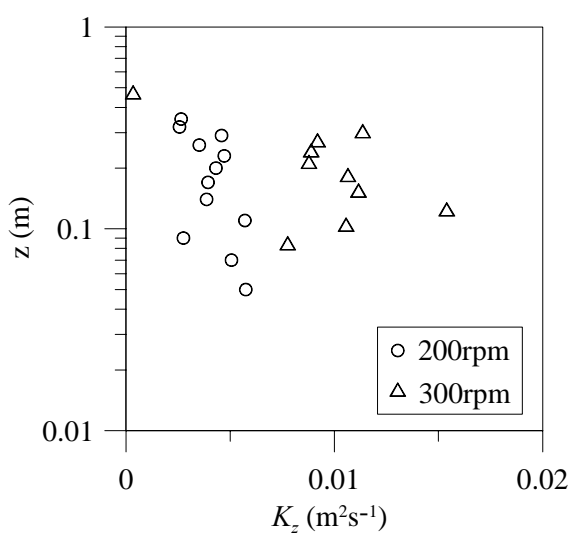

（2）渦動粘性係数の鉛直分布

図-6 乱れ成分及び渦動粘性係数

3. $46 \mathrm{~cm}^{2} / \mathrm{s}$ となった. 井上 ${ }^{5}$ は風洞の構造, 風速等

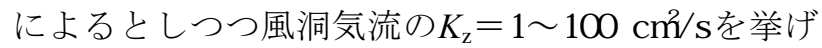
ていて，今回の実験結果はその範囲内にある.

\section{（3）波高及び波速の測定}

波高の測定は，容量式波高計（株式会社ケネック 製CH604，検出部CHT6-30，応答時間0.1 s）を用い た。風が吹き始めると水槽内の平均水位は最初の静 水面から次第に変化するので，送風開始から20分以 上の十分な時間が経過してから全ての計測を行った。

断面Cの横断方向中央位置で計測した180 sのデー タから, ゼロアップクロス法により周期及び波高を 求めた。 表- 1 に, 有義波高 $h_{1 / 3}$, 最高波高 $h_{\max }$ 及び有 義波周期 $T_{1 / 3}$ を示した。

表- 1 波高の測定結果

\begin{tabular}{c|c|c|c}
\hline $\begin{array}{c}\text { 送風機回転数 } \\
(\mathrm{rpm})\end{array}$ & $\begin{array}{c}\text { 有義波高 } \\
h_{1 / 3}(\mathrm{~cm})\end{array}$ & $\begin{array}{c}\text { 最高波高 } \\
h_{\max }(\mathrm{cm})\end{array}$ & $\begin{array}{c}\text { 有義波周期 } \\
T_{1 / 3}(\mathrm{~s})\end{array}$ \\
\hline 200 & 2.59 & 4.00 & 0.40 \\
\hline 300 & 4.06 & 6.33 & 0.49 \\
\hline
\end{tabular}

波速の測定は，上と同じ容量式波高計2台を水平 主流方向に0. $2 \mathrm{~m}$ 間隔を空けて設置し, 同時に測 定を行った. そのデータのうち20波のピークを抽出 する方法により，それぞれ波速を算定した。 その結 果，20波の波速の平均值 $\bar{c}$ は200r pm)とき0. $72 \mathrm{~m} / \mathrm{s}$, 
300 r pmのとき $0.85 \mathrm{~m} / \mathrm{s}$ となった。 (2)の の*で $\bar{c}$ を 割った值である「波齢」は1よりも大きく，断面Cの 位置で風波は十分に発達していたと考えられる。

波高及び波速の測定は気温，水温，気圧，湿度と も( 2)とほぼ同じ条件で行った。

\section{（4）流速の測定}

流速は，既往の報告3で測定した結果を用いた。 寸なわち, 電磁流速計（株式会社ケネック製VNFO6H, 直軸型検出部VMT2-200- 04P, 応答時間0.05 s）を用 い，横断方向中央位置で鉛直方向に高さを変えて測 定している. 図-7は，300r pm)ときの断面Cで3分間 の時間平均をした流速 $u_{f}$ の鈶直方向の分布である. 表層付近では吹送流による風下方向の流れ，底層付 近ではそれを補償する風上方向の流れが生じている.

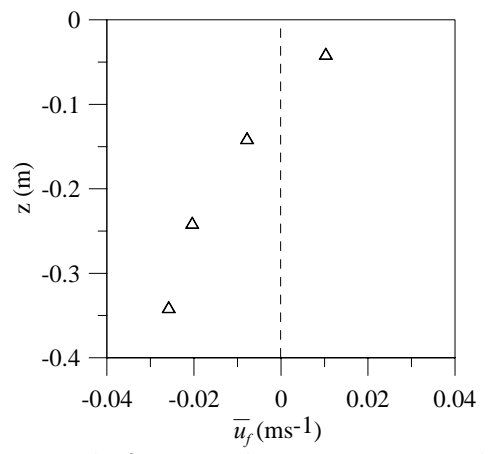

図-7 流速分布（断面C，300r pm）

\section{（5）コンテナ模型に作用するカの測定}

実物コンテナの形状は, 日本規格協会のの発行す る日本工業規格により規格されている. 図-8は, そ の規格に相似するように作成した縮尺 $s=1 / 20 の 40$ フィートコンテナ模型の諸元である。躯体はアクリ ル板（厚さ $2 \mathrm{~mm}$ 密度1. $19 \mathrm{~g} / \mathrm{cm}^{3}$ ) を接合して作ら れている.

次に，模型質量の設定方法を述べる．満載コンテ ナ模型は，重り及び空隙調整用の小部材を図-8(2) のようにコンテナ模型内部に追加して質量を調整し ている. 実物コンテナの満載質量は, 先述の日本工 業規格によると $30,480 \mathrm{~kg}$ である。模型に作用する 力の大きさ, 例えば風抗力の大きさは模型の喫水に 影響されると考えられる。 そこで, 実物コンテナの 海上での喫水に対して模型の喫水が約 $1 / 20$ になるよ う質量を調整した。その結果，模型の質量は4.051 $\mathrm{kg}$, 喫水は0.053 mとした。一方, 空載質量（自 重）は前述の規格に規定がなく，筆者ら ${ }^{7}$ の現地調 査結果を参考に質量は0.877 kg, 喫水は, 模型の浮 遊時の安定性を考慮して0.018 mとした。

海面上の模型に作用寸る力を測定寸るため, 模型 を水表面付近に固定するための台座を作成した。台 座は, 水路内部を横断する門型部とその脚部からな り, 鋼製の剛な構造である. 台座 (門型部) の天井 部分に三分力計 (株式会社共和電業製 LSMB 50NSA1）を下向きに取付ける. そこから剛な鋼棒で
コンテナ模型を吊下げて固定した．コンテナ模型は, 中心がちょうど断面の位置にくるように，また， 模型の喫水が静水面と一致するように設置した（写 真-1）. 3 . (2) で述べるように，既往の報告3)で はコンテナ模型を海面上に浮遊させて拘束せずに自

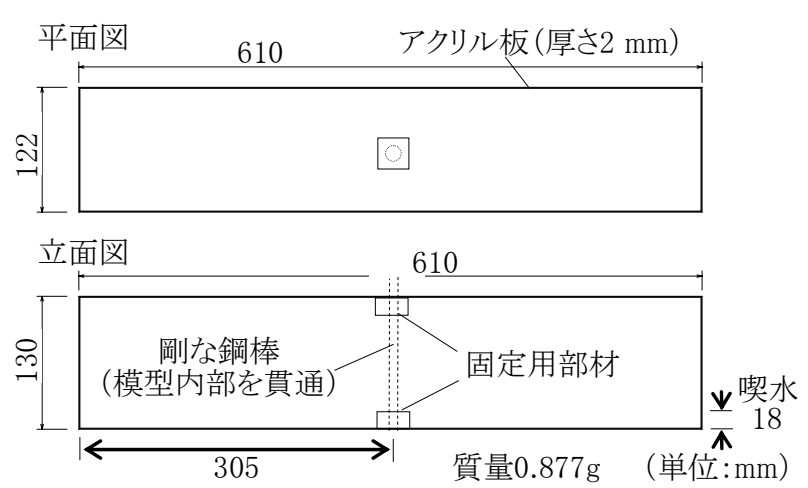

(1) 空載



(2) 満載

図-8 コンテナ模型の見取図

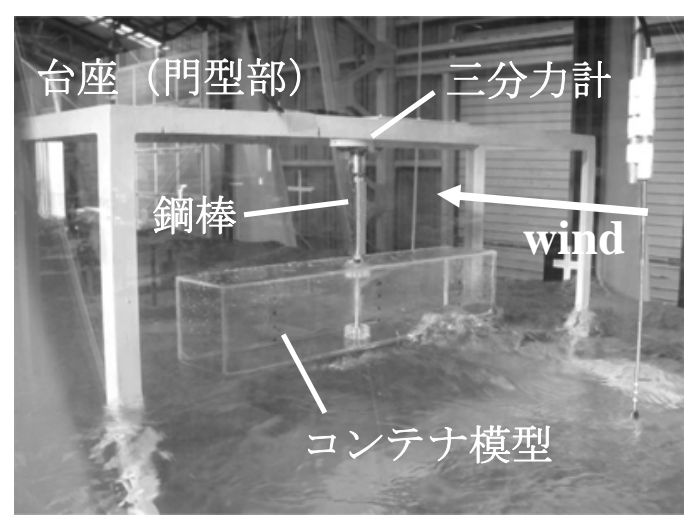

写真-1 コンテナ模型に作用する力の測定

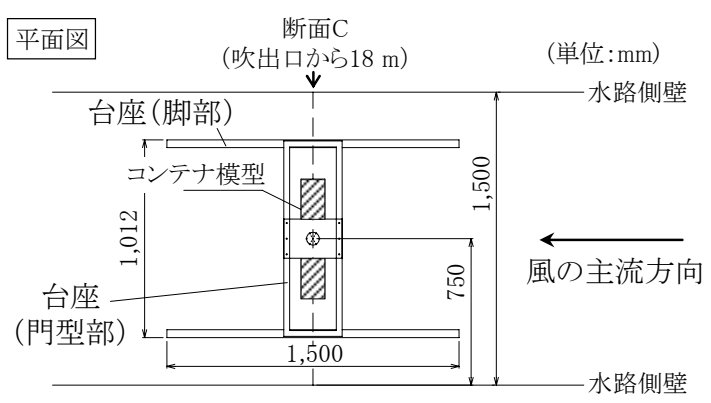

図-9 コンテナ模型の設置向き 
由状態で漂流させた場合，コンテナ模型は風の主流 方向に対して模型長軸が90度を向く方向で漂流して いた，そこで，コンテナ模型の設置向きは，風の主 流方向に対して模型長軸が90度となるようにした （図-9）.

実験は，この環境で送風機回転数を300r pmで送風 し, コンテナ模型に作用する風抗力, 流れ抗力, 波 力, 慣性力, 鋼棒に作用する風抗力の合力を測定し た。また，コンテナ模型を取り外した状態でも測定 を行うことにより，コンテナ模型を吊り下げている 鋼棒部分のみに作用する風抗力を測定した. 最初に 挙げた合力から鋼棒に作用する風抗力を差し引いて, コンテナ模型に作用する風効力, 流れ抗力, 波力及 び慣性力の合力を算定した.

\section{3. 実験結果}

\section{（1）現地への適用性}

航空機等の模型実験でおこなわれているように, 実験と現地の風の流れとを相似させるためにレイノ ルズ数 $U L / v （ U$ : 実験における代表速度， $L$ : 実験 における代表長さ， $v$ : 空気の動粘性係数）を一致 させようとすると, 実験と現地はvがほぼ同じとし て, 実験では模型の縮尺に逆比例する大きさの風速 が必要になる。すなわち，300 r pmD場合に $u_{a}$ が約8 $\mathrm{m} / \mathrm{s}$ とすと, 模型の縮尺 $s=1 / 20$ であるから, 現地 の約0.4 $\mathrm{m} / \mathrm{s}$ の風と相似していることになる.

この考え方に対し, 加藤ら ${ }^{8)}$ は, 乱流状態のとき は運動量や熱量の拡散が層流状態のときよりも大き くなることに着目し, 流体の性質を表すものは次の 関係で用いられる渦粘性係数 $A$, 寸なわち,

$$
\tau_{t}=A \frac{\partial U}{\partial z}
$$

（ $\tau_{t}$ : 乱れによる風のせん断力）が一般的であり， $A$ を流体の密度 $\rho$ で割った渦動粘性係数 $K_{\mathrm{z}}$ 用いて, 渦動粘性係数 $K_{\mathrm{z}}$ にるレイノルズ数

$$
R_{K}=\frac{U L}{A / \rho}=\frac{U L}{K_{Z}}
$$

による相似について検討している。そこで，これを 参考に現地への適用性を検討する.

実験結果より，300r pm とき $z=0.475 \mathrm{~m}$ で $K_{\mathrm{z}}=$ $3.46 \mathrm{~cm}^{2} / \mathrm{s}^{2}$ となった（2. (2) 節）.この $z=0.475$ mは, 縮尺1/20ならば, 現地で気象観測が頻繁に行 われている高さ10 mこほぼ相当する. 同じ位置の $u_{a}$ $=8.26 \mathrm{~m} / \mathrm{s}$ であり，代表長さ $L$ としてコンテナ模型 の高さ $H=0.13 \mathrm{~m}$ 選ぶと, (4) 式より $R_{K}=3,107$ と なる. 一方, 現地の渦動粘性係数について, 加藤ら 8) はかなりの幅をもつて変わりかつやや小さめであ ることを指摘しているものの, $z=10 \mathrm{~m}$ 対し現地
の渦動粘性係数 $K_{\mathrm{z} 0}=2.0 \times 10^{3} \mathrm{~cm}^{2} / \mathrm{s}$ とう值を挙げ ている.この $K_{\mathrm{z} 0}$ と実物コンテナの高さ $H_{0}=0.26 \mathrm{~m}$ を用い，先ほどの $R_{K}$ を一致させようとすれば，(4) 式より現地の風速 $U_{0}=R_{K} \cdot K_{Z 0} / H_{0} \fallingdotseq 239 \mathrm{~m} / \mathrm{s}$ とな る.わが国における平地での台風の最大風速記録は 1965年に記録された $69.8 \mathrm{~m} / \mathrm{s}$ あ゙あり，それと比べる と実験の風速は大きな值となっているようである. 一方, 吹送距離 $x=18 \mathrm{~m}$ の位置で容量式波高計を用い 測定した風波に，フルードの相似則を適用すると， 現地では $h_{1 / 3}=0.518 \sim 0.812 \mathrm{~m}, \quad T_{1 / 3}=1.8 \sim 2.2 \mathrm{~s}$ 概ね 妥当な波浪場に相当していた。 このように, 風速に ついては現地よりも大きな值を与えているようであ り，乱れを小さくした条件とするなどより詳細に実 験条件を調整することが必要である。

\section{（2）コンテナ模型に作用するカ}

図-10は，既往の報告 ${ }^{3}$ における，300r pm 満載 の場合のコンテナ模型を自由状態で漂流させた場合 の漂流軌跡及び移動速度である。(1) は, $t=0.0 \mathrm{~s}$ に拘束を解かれた模型が，右から左方向にむかって 移動する軌跡を0. $5 \mathrm{~s}$ 間隔で示す. 棒線は模型の中 心軸位置である。 ( 2) は, その座標位置から算出し た移動速度 $u_{m}$ の時間変動を示す. $u_{m}$ は比較的短い周 期で変動しているものの, $t=2 \mathrm{~s}$ 程度よりあとは平 均的には0.2 $\mathrm{m} / \mathrm{s}$ 程度の移動速度で漂流する。 そこ で，図-11のような状態を仮定する。風波はコンテ ナ模型を追い越す際に模型を摇動させるが，平均的 には，風抗力 $F_{a}$ と流れ抗力 $F_{f}$ が釣り合うと仮定する. なお， $F_{a}$ は風の主流方向に正方向の力， $F_{f}$ は模型の 移動速度が吹送流の流速よりも大きいため模型の移 動速度とは逆向き方向, 寸なわち風の主流方向に負 方向の力である. $F_{a}$ と流れ抗力 $F_{f}$ は, 流体と物体と

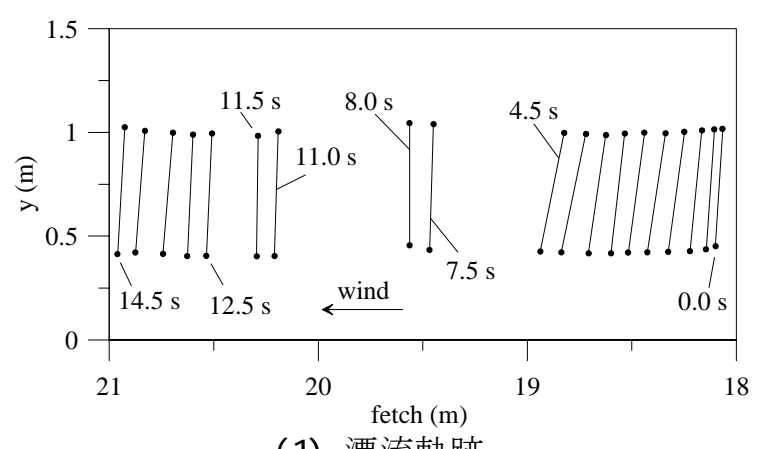

(1) 漂流軌跡

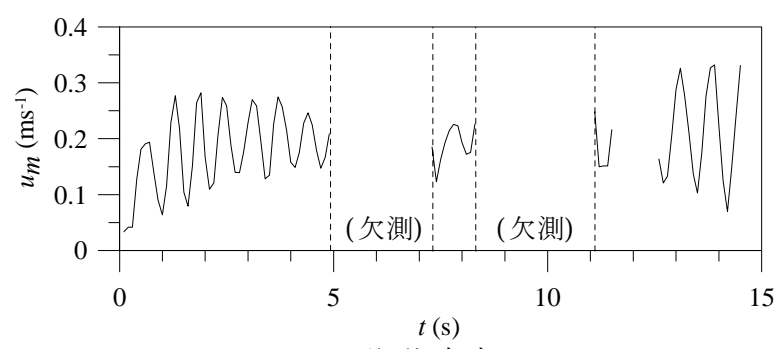

(2) 移動速度

図-10 漂流軌跡と移動速度（300r pm 満載） 


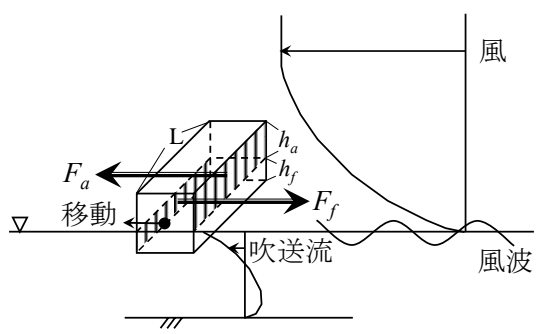

図-11 自由状態で漂流させた場合の作用する力

の相対速度の2乗に比例する形の式が一般的に用い られていて,

$$
\begin{aligned}
& F_{a}=\frac{1}{2} C_{a} \rho_{a} u_{a}^{\prime}\left|u_{a}^{\prime}\right| A_{a} \\
& F_{f}=\frac{1}{2} C_{d} \rho_{w} u_{f}^{\prime}\left|u_{f}^{\prime}\right| A_{f}
\end{aligned}
$$

ここで, $C_{a}$ : 風抗力係数, $\rho_{a}$ : 空気の密度, $u_{a}^{\prime}$ : 風速 $u_{a}$ に対する模型の相対速度, $A_{a}$ : 気中部分の受 圧面積, $C_{d}$ : 流れ抗力係数, $\rho_{w}$ : 水の密度, $u_{f}^{\prime}$ : 流速 $u_{f}$ に対する模型の相対速度, $A_{f}$ : 水中部分の受 圧面積である. (5) 式の右辺と (6) 式の右辺とが等し いとすれば, $300 \mathrm{rpm}$ 満載のときの $C_{a}: C_{d}=0.30: 1$ となった。ここで，2．（5)で得られた合力の時間 平均值は, 300r pm 満載の場合に1.584 Nであった ので, $\rho_{w}=1,000 \mathrm{~kg} / \mathrm{m}^{3}, A_{f}=0.0323 \mathrm{~m}^{2}, u_{f}=0.0103$ $\mathrm{m} / \mathrm{s}, \quad \rho_{a}=1.21 \mathrm{~kg} / \mathrm{m}^{3}, \quad A_{a}=0.0470 \mathrm{~m}^{2}, \quad u_{a}=8.26$ $\mathrm{m} / \mathrm{s}$ とし $, C_{a}=0.815, C_{d}=2.72$ となった.

既往の適用事例と比較すると, 本田ら ${ }^{9}$ が $C_{a}=$ 0.681を提案している.これは，ふ頭上の直立した 固定壁として陸上で実物コンテナの風抗力を測定し た結果であり，今回の結果はこれに比較するとやや 大きくなった。 Dani el et al. ${ }^{2}$ は， $u_{a}$ の定義位置 を海面上 $10 \mathrm{~m} と し て C_{a}=1.0$ 用い, $u_{f}$ の定義位置 は特に明示していないが $C_{d}=1.0$ の值を用いている. ただし，これは数值計算にあたっての仮定条件とし て与えたものであるが，今回の結果はやや $C_{d}$ に関し ては大きいようである。これについては, 波力の適 切な考慮等のより詳細な検討が必要であると考えら れる。また，清宮 ${ }^{10}$ は，海上の浮体構造物の受ける 流れ風抗力として $C_{a}=1.2$ としているが，この算定 にあたっては風速の定義位置を高さ10 m位置の風速 $U_{10}$ ではなく, 浮体構造物高さ中心位置の風速を用 いており, 単純な比較が難しい。また, 貨物積載の 影響として, 空載と満載とを比較すると, 流れ抗力 係数に対する比率は, 満載のときの風抗力係数より も空載のときの風抗力係数の方が大きくなる傾向が みられた。

今回は，コンテナ模型を台座に固定して実験を 行っているため海面の上下動に連動しないかたちに なっているが, 実際には海面の上下動にあわせて漂 流物も上下しているので，その影響を考慮できてい ない。 また，風向きに対して直立に固定しているが，
風を逃がすよう傾いて漂流することも観察された. これらの挙動が及ぼす影響についても，今後詳細に 検討を加えていく必要がある.

\section{4. 結論}

風の吹く海域を模擬した風洞水槽においてコンテ ナ模型を用いた実験を行った。

まず，現地の波浪場及び風場への適用性を検討し， 波浪場については概衫適用できると考えられるが, 風場については現地よりも大きな值を与えているよ うであり乱れを小さくした条件とするなど今後の詳 細な検討が必要であることが分かった。

また，模型に作用寸る風抗力係数及び流れ抗力係 数について満載で送風量が比較的大きい場合の值を 算定し既往の提案されている值との比較を行い，ふ 頭上で実物コンテナの風抗力を測定した既往の結果 と比較すると風抗力係数はやや大きかった. 流れ抗 力についても，一般的に用いられているものよりも 大きくなる結果となり, 波力の適切な考慮等のより 詳細な検討が必要であると考えられる.

謝辞：本研究を行うにあたり，株式会社エコー長谷 川嚴氏をはじめ各位に風洞実験の実施についてご助 力を頂きました。ここに記して謝意を表します.

\section{参考文献}

1) Fanch, C. and Yannick A.: Criteria for Decision Making Regarding Response to Accidentally Spilled Chemicals in Packaged Form: Hydrodynamic Aspects, Spill Science \& Technology Bulletin, Vol. 4, No.1, pp.7-15, 1997.

2) Daniel, P., Gwenaele, J., Fanch, C., Landau, Y. and Loiseau, E.: Drift Modeling of Cargo Containers, Spill Science \& Technology Bulletin, Vol. 7, No.5-6, pp.279-288, 2002.

3) 熊谷兼太郎, 鈴木武: 風洞水槽におけるコンテナ模型 の流動に関する基礎的実験，海洋開発論文集，第 26 巻, pp. 951- 956, 2010.

4) 加藤始, 竹村莞爾 : 水面上の風速分布（第 1 報）, 港 湾技術研究所報告, 第 5 巻 1 号, pp. 15-16, 1966.

5) 井上榮一: 自然の風々風洞実験・第 2 報, 応用力学, 第 4 巻，第 22 号, pp. 3 6, 1951.

6) 日本規格協会 : 国際貨物コンテナー外のり寸法及び最 大総質量, JIS Z 1614, 8p, 1994.

7) 熊谷兼太郎, 小田勝也, 藤井直樹 : コンテナ沈没挙動 の現地実験と港湾における漂流数值シミュレーション, 海岸工学論文集, 土木学会, 第 55 巻, pp. 271- 275, 2008.

8) 加藤始, 佐野喜久雄 : 風洞におけるウインドスクリー ンの模型実験，港湾技術研究所報告，第 11 巻，第 1 号, pp. 23 66, 1972.

9) 本田啓之輔, 堀富士男: コンテナの耐風に関する模型 実験, 日本航海学会論文集, pp. 29-34, 1980.

10) 清宮理 : 海上風の性質とそれによるく（矩）形浮体の 動摇解析, 港湾技術研究所報告, 第 19 巻第 2 号, pp. 115-167, 1980. 